\author{
Case Report \\ www.ijrap.net (ISSN:2229-3566)
}

\title{
PATALA PANEEYA KSHARA IN URINARY TRACT INFECTION: A CASE REPORT
}

M.S. Anju *1, M.M. Abdul Shukkoor ${ }^{2}$, S. Aneesh ${ }^{3}$

${ }^{1}$ PG Scholar, Department of Shalya tantra, Government Ayurveda College, Tripunithura, Ernakulam Kerala, India

${ }^{2}$ Professor, Department of Shalya tantra, Government Ayurveda College, Tripunithura, Ernakulam, Kerala, India

${ }^{3}$ Assistant Professor, Department of Shalya tantra, Government Ayurveda College, Tripunithura, Ernakulam, Kerala

Received on: 26/10/20 Accepted on: 18/01/21

\author{
*Corresponding author \\ E-mail: anjums2017@gmail.com
}

DOI: $10.7897 / 2277-4343.12014$

\begin{abstract}
Urinary tract infections (UTI) affect men and women of all ages. The disease varies dramatically in their presentation and sequel. They are common cause of morbidity among people and can lead to significant mortality. E. coli is the most common organism causing UTI. The symptoms from a urinary tract infection include dysuria, frequent urination, burning sensation, urgency, hematuria and fever. Mutrakrichra which is having similar symptoms to UTI is widely described in Ayurveda classics. It is a tridoshaja vyadhi. Kshara is one among the important formulation that can be effectively used for the treatment of Mutrakrichra. Patala Paneeya kshara is indicated in treatment of Kaphaja Mutrakrichra by Acharya Vagbhata. A 43-year-old male got admitted with IP No.1069 in the hospital with symptoms of dysuria, suprapubic pain, urgency and increased frequency of micturition. After urinalysis condition was diagnosed as UTI. Prakruti of the patient was assessed as Vatakaphaja and found out to be suitable for internal administration of kshara. Patient was administered $500 \mathrm{mg}$ capsules of Patala paneeya kshara twice daily for a period of 10 days and analyzed the condition. Along with reduction in number of pus cells great symptomatic relief was obtained. With the indigenous properties of kshara it can be effectively used in treatment of UTI.
\end{abstract}

Keywords: Urinary Tract Infection, Patala Paneeya Kshara

\section{INTRODUCTION}

Urinary Tract Infection is the $3^{\text {rd }}$ most infection affecting population world-wide ${ }^{1}$. It is common in women of child bearing age and in older individuals. The clinical features, diagnosis, treatment and prognosis vary depending on -

- Causative organism

- Site of infection

- Structural and functional integrity of the urinary tract

Subjects present with symptoms of dysuria, increased frequency of urination, urgency, burning sensation, suprapubic pain, haematuria $^{2}$. Treatment of conventional medicine aims in identifying and treating predisposing organism, eradicate infective organism using antimicrobials, altering $\mathrm{pH}$ of urine to provide symptomatic relief and prevent and treat recurrence of $\mathrm{UTI}^{3}$.

In Ayurveda there exist a wide description about mutra rogas and their management. They include Mutrakrichra, Ashmari and Mutraghata. While analyzing all these Mutrakrichra is the disease with similar signs and symptoms as that of UTI. Mutrakrichra is a tridoshaja vyadhi and exhibit features with dominant Dosha vitiation and symptoms vary likewise. Generally, patients present with bastinistoda, muhurmuhu mutra pravruti, daha, gurutwa etc. Various Shamana and Shodhana therapies are mentioned in the treatment of mutrakrichra ${ }^{4}$.

Kshara is indicated in treatment of Mutrakrichra in Rasa Tarangini ${ }^{5}$. Kshara is best among sastra and anusastra according to acharya Sushruta. Kshara possess Pachana, Deepana, kledasoshana and tridoshahara property ${ }^{6}$ by which can be effectively employed in Mutrakrichra chikitsa. Patala paneeya kshara is indicated in the treatment of Kaphaja Mutrakrichra by Acharya Vagbhata in Ashtanga Hrdaya ${ }^{7}$.

\section{Case report}

A 43-year-old male admitted in Shalya Tantra department of the hospital with IP No.1069 presented with complaints of Bastinistoda (suprapubic discomfort), dysuria, urgency muhurmuhu mutra pravruti (increased urine frequency), itching of periurethral area. According to the patient symptoms started 2 days back and he noticed turbid urine. Patient had a previous attack of UTI 2 weeks back which got resolved by antibiotics. Patient had no history of renal calculi.

Physical examination of urinary system was done and no abnormality was detected. There were any abnormalities in inspection and also there was no tenderness over suprapubic region. Urinalysis was done. It showed 30-35 pus cells/hpf and the patient was diagnosed with Urinary Tract Infection (ICD 10 N39).

\section{Dasha Vidha Pareeksha}

Dushya: Dosha - Kapha, Vata, Pitta Dushya - Rasa, Rakta

Desha: Deha desham: Basti Bhumi desham: Anupam

Bala: Avaram

Kala: Kshanadi - sarat Vyadhyavastha - navam

Anala: Mandam

Prakruti: Vatakapha

Vaya: Madhyama

Satwa: Madhyama

Satmya: Avyayamam

Aharavastha: Aharashakti - avaram Jaranashakti - avaram 


\section{MATERIALS AND METHODS}

After analyzing Dasha Vidha Pareeksha and Ashta Sthana Pareeksha it was made sure that the patient is suitable for kshara administration. Patient was provided with $500 \mathrm{mg}$ Patala paneeya kshara capsules and advised drug intake twice daily; morning and evening after food for a period of 10 days.

Informed consent was obtained prior to intervention and intervention was done as per International conference of Harmonization-Good Clinical Practices Guidelines (ICH-GCP).

\section{Drug preparation}

Bark of Patala (Stereospermum suaveolens DC) ${ }^{8}$ was collected, cleaned and dried. Drug burnt and ash obtained was collected. Patala Paneeya Kshara was prepared according to the reference in Rasa Tarangini ${ }^{9}$ and was capsulated at a dose of $500 \mathrm{mg}$ to prevent any mucosal irritation.

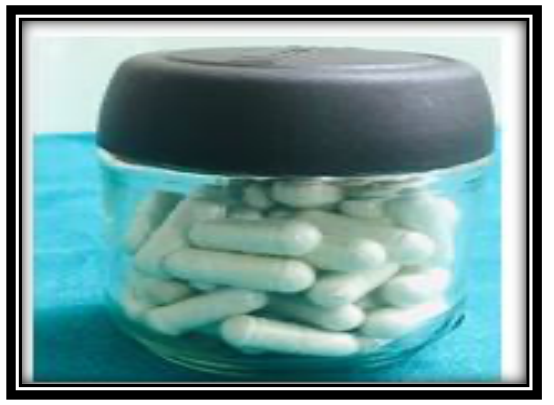

Figure 1: Patala paneeya kshara

\section{Observation}

The condition of the patient was observed and periodically analyzed. Changes in symptoms of UTI and urinalysis were observed.

\section{a) Dysuria}

Patient presented with regular bearable dysuria and by $3^{\text {rd }}$ day there was only mild and occasional pain. And by $7^{\text {th }}$ day patient get rid of the symptom.

\section{b) Suprapubic pain}

Suprapubic pain was mild and occasional at first and got relieved in 3 days

\section{c) Frequency}

At presenting patient had to urinate about half the time in less than every two hours. This reduced to less than half the time in 3 days and in 7 days, the symptom got relieved.

\section{d) Urgency}

Patient presented with difficulty to postpone urination about half the time and in 5 days difficulty to postpone urination reduced to less than half the time and in total of 10 days symptoms subsided.

Along with these findings patient also reported that urine became clear in 5 days which was turbid before. Also itching in periurethral area got subsided.

Table 1: Analysis of symptoms

\begin{tabular}{|c|c|c|c|c|}
\hline & $15 / 7 / 19$ & $18 / 7 / 19$ & $20 / 7 / 19$ & $22 / 7 / 19$ \\
\hline Dysuria & Regular bearable & Mild and occasional pain & Even reduced & Relieved \\
\hline Suprapubic pain & Mild and occasional & Relieved & 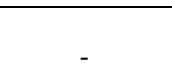 & 20 \\
\hline $\begin{array}{c}\text { Frequency } \\
\text { urinate about half the time in }<\text { every } 2 \text { hours }\end{array}$ & about half the time & less than half the time & Relieved & - \\
\hline $\begin{array}{c}\text { Urgency } \\
\text { (difficulty to postpone urination) }\end{array}$ & about half the time & less than half the time & Relieved & - \\
\hline
\end{tabular}

Table 2: Urinalysis

\begin{tabular}{|c|c|c|c|c|c|}
\hline & 15.7 .19 & 20.7 .19 & 25.7 .19 & 31.7 .19 & 05.8.19 \\
\hline Colour & Pale yellow & Pale yellow & Pale yellow & Pale yellow & Pale yellow \\
\hline pH & 6.5 & 6.5 & 6.5 & 6 & 6 \\
\hline Sp. gravity & 1.005 & 1.005 & 1.005 & 1.005 & 1.005 \\
\hline Casts & Nil & Nil & Nil & Nil & Nil \\
\hline RBC & $0-1$ & Nil & Nil & Nil & Nil \\
\hline WBC & $30-35$ & $20-25$ & $15-20$ & $10-15$ & $4-6$ \\
\hline Epithelial cells & Nil & Nil & Nil & Nil & Nil \\
\hline Bacteria & Nil & Nil & Nil & Nil & Nil \\
\hline
\end{tabular}

\section{RESULTS}

From the above observations it is evident that the patient got symptomatic relief after the administration of Patala paneeya kshara. The symptoms like dysuria, suprapubic pain, urgency and frequency get reduced during the treatment and follow up period. Also, the amount of pus cells showed a gradual reduction during treatment period indicating the anti-inflammatory property of the drug.

\section{DISCUSSION}

The action of kshara formulation along with the properties of drug Patala may have enacted to get the current results. Patala kshara contain sodium and potassium ions. Sodium and potassium in carbonate form act as alkalizing agent and helped to reduce symptoms like urgency and frequency. $\mathrm{pH}$ of Patala paneeya kshara (12.29) also contribute to this. In the management of UTI it is important to maintain the urine $\mathrm{pH}$. 
Patala is one among the Shothahara Mahakashaya gana by Acharya Charaka ${ }^{10}$. Tikta, katu and kashaya rasa of patala help in kleda shoshana. The mutrashoshana property of tikta rasa get compensated by madhura rasa and guru guna of the drug itself and acted as mutrala. Katu rasa act on amatwa and kha vaigunya and result in Shroto shodhana. Also, the drug is tridoshahara. Bark of Patala contained pentosan, lignin, phenolic benzaldehydes which are helpful in reducing bladder pain, reducing bacterial activity respectively ${ }^{11-13}$.

Kshara by its ksharana property results in cause pacification of vitiated doshas. Kshara possess pachana, deepana, amahara properties and helps in alleviating the annajirna caused by nidanas of mutrakrichra. By ushna, tikshna gunas of kshara along with kleda shoshana property, vitiated kleda brought to normalcy. By this mutra became nirama and results in anavila, apichala and visada mutra. And hence the results are obtained.

\section{CONCLUSION}

After analyzing the pre- and post-interventional data, it is understood that the drug acted effectively in reducing the number of pus cells. $\mathrm{pH}$ of urine was maintained in normal limit without any fluctuation.

Patala Paneeya Kshara is highly effective in reducing the symptoms of Urinary Tract Infection.

\section{ACKNOWLEDGEMENT}

Author is thankful to Department of Shalya Tantra Government Ayurveda College Tripunithura for all the support and suggestions for this study.

\section{REFERENCES}

1. Najar MS, Saldanha CL, Banday KA. Approach to urinary tract infections. Indian Journal of Nephrology 2009 Oct; 19(4): 129.

2. Wein, Kavoussi, Novick, Partin, Peters. Campbell-Walsh Urolgy. $10^{\text {th }}$ Ed. USA: Elsevier Saunders; 2012. p. 257.

3. Satoskar, RS. Rege, Nirmala. Bhandarkar, SD. Pharmacology AND Pharmacotherapeutics. $25^{\text {th }}$ ed. New Delhi: Elsevier India; 2017. p. 731.

4. Sharma PV. Suśruta-saṃhitā: with English translation of text and Dalhanas commentary along with critical notes.
Varanasi: Chaukhambha Vishwabharati. Uttara tantra. Mutrakrichra Pratishedha; 2010. p. 579-583.

5. Angadi R. Rasa taranginiñ: Āyurveda pharmaceutics and Indian alchemy of Śrī Sadānanda Śarmā: with Transcendence descriptive English commentary. Varanasi: Chaukhambha Surbharati Prakashan; 2015. p. 229.

6. Sharma PV. Suśruta-saṃhitā: with English translation of text and Dalhanas commentary along with critical notes. Varanasi: Chaukhambha Vishwabharati. Sutra Sthana. Ksharapakavidhi adhyaya; 2010. p. 113-115.

7. Srikanta Murthy KR Vāgbhațas Așțānga Hrodayam: text, English translation, notes, appendix, and indices. Varanasi: Krishnadas Academy. Chikitsa Sthana. Mutraghata Chikitsa; 2013. p. 373.

8. The Ayurvedic Pharmacopoeia of India. New Delhi: Govt. of India, Ministry of Health and Family Welfare, Department of Ayurveda, Yoga and Naturopathy, Unani, Siddha, and Homoeopathy; 2007.

9. Angadi R. Rasa tarangin̄ī: Āyurveda pharmaceutics and Indian alchemy of Śrī Sadānanda Śarmā: with Transcendence descriptive English commentary. Varanasi: Chaukhambha Surbharati Prakashan; 2015. p. 228.

10. Śarmā Rāmakaraṇa, Dash B, Agniveśa. Agniveśas Charaka Saṃhitā: text with English translation and critical exposition based on (Chakrapāṇi Dattas Āyurveda dīpikā). Varanasi: Chaukhambha Sanskrit Series Office. Sutra Sthana; 2012. p. 97.

11. Teichman JM. The role of pentosan Polysulfate in treatment approaches for interstitial cystitis. Reviews in urology 2002; 4(Suppl 1): S21.

12. Spiridon I, Poni P, Ghica G. Biological and pharmaceutical applications of lignin and its derivatives: a mini-review. Cellul Chem Technol 2018 Jul 1; 52(7-8): 543-50.

13. Antibacterial activities of phenolic benzaldehydes and benzoic acids against Campylobacter jejuni, Escherichia coli, Listeria monocytogenes, and Salmonella enterica. J food prot 2003 Oct; 66(10): 1811-21.

\section{Cite this article as:}

M. S. Anju et al. Patala Paneeya Kshara in Urinary Tract Infection: A Case Report. Int. J. Res. Ayurveda Pharm. 2021;12(1):12-14 http://dx.doi.org/10.7897/2277-4343.12014

Disclaimer: IJRAP is solely owned by Moksha Publishing House - A non-profit publishing house, dedicated to publishing quality research, while every effort has been taken to verify the accuracy of the content published in our Journal. IJRAP cannot accept any responsibility or liability for the site content and articles published. The views expressed in articles by our contributing authors are not necessarily those of IJRAP editor or editorial board members. 